\title{
Synthesis and Catalytic Activity of $\mu$-Oxo Ruthenium(IV) Porphyrin Species to Promote Amination Reactions
}

\author{
Paolo Zardi, ${ }^{a}$ Daniela Intrieri, ${ }^{b}$ Daniela Maria Carminati ${ }^{b}$ Francesco Ferretti, ${ }^{b}$ Piero \\ Macchi $^{c}$ and Emma Gallo ${ }^{b_{*}}$
}

${ }^{a}$ Department of Chemical Sciences of Padua University, Via F. Marzolo, 1 - 35131 Padua (I) ${ }^{b}$ Chemistry Department of Milan University, Via C. Golgi 19, 20133 Milan (I), ${ }^{c}$ Department of Chemistry and Biochemistry of University of Berne,

Freiestrasse 3, CH-3012 Berne (CH),

E-mail:emma.gallo@unimi.it

Received date (to be automatically inserted after your manuscript is submitted)

Accepted date (to be automatically inserted after your manuscript is accepted)

\begin{abstract}
This work describes the synthesis of ruthenium(IV) $\mu$-oxo porphyrin complexes of general formula $\left[\mathrm{Ru}^{\mathrm{IV}}(\mathrm{TPP})(\mathrm{X})\right]_{2} \mathrm{O}$ which have been applied as catalysts in nitrene transfer reactions using aryl azides $\left(\mathrm{ArN}_{3}\right)$ as nitrene sources. Collected data indicated that the catalytic efficiency of $\left[\mathrm{Ru}^{\mathrm{IV}}(\mathrm{TPP})\left(\mathrm{OCH}_{3}\right)\right]_{2} \mathrm{O}$ was comparable to that of $\mathrm{Ru}^{\mathrm{II}}(\mathrm{TPP}) \mathrm{CO}$ because of their analogous reactivity towards aryl azides to give the same catalytically active bis-imido species $\mathrm{Ru}^{\mathrm{VI}}(\mathrm{TPP})(\mathrm{ArN})_{2}$. The reaction of $\left[\mathrm{Ru}^{\mathrm{IV}}(\mathrm{TPP})\left(\mathrm{OCH}_{3}\right)\right]_{2} \mathrm{O}$ with $\mathrm{Ph}_{3} \mathrm{CN}_{3}$ or $\left(\mathrm{CH}_{3}\right)_{3} \mathrm{SiN}_{3}$ afforded $\left[\mathrm{Ru}^{\mathrm{IV}}(\mathrm{TPP})\left(\mathrm{N}_{3}\right)\right]_{2} \mathrm{O}$ which was fully characterised, its molecular structure was also determined by single crystal $\mathrm{X}$-ray analysis.
\end{abstract}

KEYWORDS: Homogeneous catalysis, Ruthenium, Amination, Azide

Correspondence to: Chemistry Department of Milan University, Via Golgi 19, 20133 Milan, Italy. e-mail: emma.gallo@unimi.it

\section{INTRODUCTION}

The development of efficient synthetic procedures to attain aminated compounds is of paramount importance due to pharmaceutical and/or biologic behaviours of aza-containing molecules.[1] Amongst all the catalysts capable of promoting amination reactions, ruthenium(II) porphyrin complexes [2-4] show a good efficiency in catalysing the amination of saturated and unsaturated hydrocarbons by using different classes of aminating agents such as aryl iminoiodinanes ( $\mathrm{RN}=\mathrm{IAr}$ ) [5], amines in the presence of oxidant species [6] and organic azides $\left(\mathrm{RN}_{3}\right)$ [7-11]. Numerous structural modifications of the porphyrin skeleton were carried out to improve the catalytic performance which can also be modulated by the electronic nature of the axial ligands onto the ruthenium(II) centre [12, 13]. Based on the fact that the catalytic activity can be fine-tuned by the metal oxidation state, ruthenium(IV) $[14,15]$ and ruthenium(VI) $[10,16$, 17] porphyrin catalysts were tested and their catalytic efficiency were compared to that of ruthenium(II) porphyrin complexes. Recorded data showed that high-valent ruthenium species are competent amination catalysts which strongly 
reinforce the hypothesis of their formation during ruthenium(II)-catalysed reactions, as suggested by several theoretical investigations [18-20].

Concerning the use of ruthenium(IV) porphyrin catalysts, C. M. Che and co-authors reported very good results on the activity of differently substituted $\mathrm{Ru}^{\mathrm{IV}}$ (porphyrin) $\mathrm{Cl}_{2}[14,15]$ complexes to promote $\mathrm{C}-\mathrm{H}$ bond nitrene insertions but, to the best of our knowledge, the catalytic activity of dimeric ruthenium(IV) porphyrin species to promote amination reactions have not yet been reported. The synthesis of oxo-bridged dimers was studied in the early 80's [21] and is favoured by using ruthenium(II)-carbonyl complexes of unhindered porphyrin ligands [22, 23], such as TPP (TPP = dianion of tetraphenylporphyrin) and OEP (OEP = dianion of octaethylporphyrin) as starting materials. The first report concerns the oxidation of $\mathrm{Ru}^{\mathrm{II}}(\mathrm{OEP}) \mathrm{CO}$ by tert-butylhydroperoxide to yield the $\mu$-oxo complex $\left[\mathrm{Ru}^{\mathrm{IV}}(\mathrm{OEP})(\mathrm{OH})\right]_{2} \mathrm{O}$ [24], which showed an unexpected stability. In fact $\mu$-oxo dimers can easily exchange the axial ligand under acidic conditions achieving compounds of the general formula $\left[\mathrm{Ru}^{\mathrm{IV}}\right.$ (porphyrin)( $\left.\left.\mathrm{L}\right)\right]_{2} \mathrm{O}$ [21]. The catalytic employment of $\mu$-oxo ruthenium porphyrins is scarce and only recently $\mathrm{R}$. Zhang and co-workers $[25,26]$ reported on the use of these dimeric species in promoting the oxidation of hydrocarbons upon photochemical activation.

Hence, we focused our attention on the synthesis of $\mu$-oxo ruthenium porphyrin complexes to investigate their reactivity with organic azides and their catalytic activity in amination reactions.

\section{RESULTS AND DISCUSSION}

We started studying the reaction of $\left[\mathrm{Ru}^{\mathrm{II}}(\mathrm{TPP})(\mathrm{CO})(\mathrm{MeOH})\right](\mathbf{1})$ with $m \mathrm{CPBA}$ (meta-chloroperbenzoic acid) which formed $\left[\mathrm{Ru}^{\mathrm{IV}}(\mathrm{TPP})(m \mathrm{CB})\right]_{2} \mathrm{O}$ complex (2) where two meta-chlorobenzoate $(m \mathrm{CB})$ anions were present on the ruthenium axial positions. Complex 2 was unequivocally identified by MS and NMR spectroscopy which showed strongly shifted signals for the aromatic protons of $m \mathrm{CB}$ moieties. We also observed the typical signal pattern of a $\mu$-oxo tetraphenylporphyrin complex, where the aromatic protons of the meso-phenyl groups were split into five different signals (Figure 1). Complex 2 was obtained in a 39\% yield and the missing mass balance was due to the partial decomposition of 2 into $\left[\mathrm{Ru}^{\mathrm{IV}}(\mathrm{TPP})\left(\mathrm{OCH}_{3}\right)\right]_{2} \mathrm{O}$ (3) during the chromatographic purification with $\mathrm{CH}_{2} \mathrm{Cl}_{2} / \mathrm{MeOH}$. Complex 3 was obtained in a 40\% yield and recorded analytical data were in accord to those reported in literature [21].

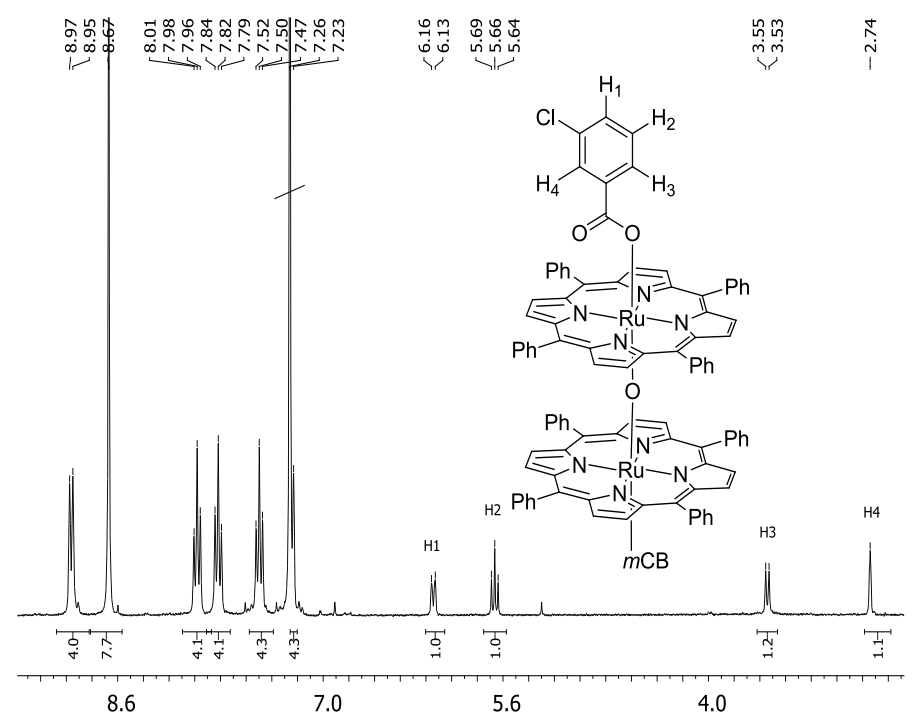

Figure 1. Structure and ${ }^{1} \mathrm{H}$ NMR spectrum of $\left[\mathrm{Ru}^{\mathrm{IV}}(\mathrm{TPP})(m \mathrm{CB})\right]_{2} \mathrm{O}$ complex (2). 
We synthesised complex 3 in high yields ( $81 \%$ yield) by reacting complex 1 with a slight excess of the oxidant $m \mathrm{CPBA}$ (8,0 eq.) in a $\mathrm{MeOH} / \mathrm{CH}_{2} \mathrm{Cl}_{2}$ mixture in the convenient ratio of 10:1, which limited the formation of complex 2 and assured the complete conversion of the starting complex $\mathbf{1}$.

Complexes $\mathbf{2}$ and $\mathbf{3}$ were both tested as catalysts of the cumene amination and only complex $\mathbf{3}$ promoted the synthesis of the corresponding benzylic amine in 65\% yield (entry 1, Table 1). Thus, complex 3 was tested as the catalyst for the nitrene transfer reactions shown in Scheme $\mathbf{1}$ by using aryl azides as nitrogen sources and obtained azaderivatives are reported in Table 1.

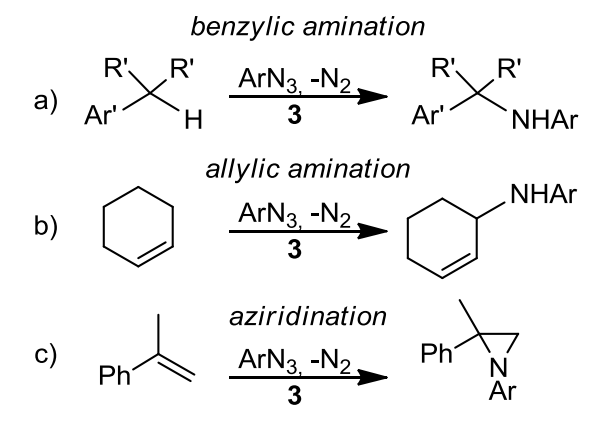

Scheme 1. Nitrene transfer reactions catalysed by complex 3 .

As shown in Table 1, compound 3 was active in promoting benzylic (entries 1-7) and allylic (entry 8) aminations as well as aziridination reactions (entry 9). In order to evaluate the catalytic efficiency of $\mathbf{3}$ for the benzylic amination, the amination of cumene was run in the presence of the low catalyst loading of $0.025 \%$ mol to obtain 4 in $65 \%$ yield. Complex 3 was also active in promoting the amination of less reactive benzylic substrates such as methyl phenylacetate (entry 6) and methyl dihydrocinnamate (entry 7), which were transformed into corresponding amino esters $\mathbf{9}$ and $\mathbf{1 0 .}$ Concerning the allylic amination of cyclohexene (entry 8) the reaction efficiency was independent from the electronic feature of the starting azide and similar yields were achieved in the synthesis of compounds $\mathbf{1 1}$ and $\mathbf{1 2}$. The low yield obtained in the synthesis of compound $\mathbf{1 3}$ can be due to a partial inhibition of the catalytic activity by the coordination of the substrate methoxy group to the ruthenium centre. As reported in entry 9 of Table 1, complex 3 was also a very good catalyst for the aziridination of $\alpha$-methylstyrene which afforded the desired aziridine $\mathbf{1 4}$ in a very short reaction time and a quantitative yield. Even if $\mathbf{3}$ demonstrated to be a competent and versatile amination catalyst, collected catalytic data are comparable to those already achieved by using $\mathrm{Ru}(\mathrm{TPP}) \mathrm{CO}(\mathbf{1 5})$ as the catalytic species $[10,11,18$, 27].

\section{Insert Table 1}

In view of the observed similarity between the catalytic behaviour of complexes $\left[\mathrm{Ru}^{\mathrm{IV}}(\mathrm{TPP})\left(\mathrm{OCH}_{3}\right)\right]_{2} \mathrm{O}(\mathbf{3})$ and $\mathrm{Ru}^{\mathrm{II}}(\mathrm{TPP})(\mathrm{CO})(\mathbf{1 5})$, we reacted $\mu$-oxo derivatives $\mathbf{2}$ and $\mathbf{3}$ with a slight excess of 3,5-bis(trifluoromethyl)phenyl azide $(\mathrm{Ru} /$ azide $=1: 3)$ in order to discover the nature of catalytic intermediates and to investigate whether similar or different mechanistic pathways are involved when ruthenium(IV) catalysts are used instead of ruthenium(II) complexes.

Complex 2 did not react with 3,5-bis(trifluoromethyl)phenyl azide even under light irradiation, whilst 3 was converted into the bis-imido $\mathrm{Ru}^{\mathrm{VI}}(\mathrm{TPP})\left(3,5-\left(\mathrm{CF}_{3}\right)_{2} \mathrm{C}_{6} \mathrm{H}_{3} \mathrm{~N}\right)_{2}(\mathbf{1 6})$ after $4 \mathrm{~h}$ (Scheme 2). As already reported [10, 17], complex $\mathbf{1 6}$ can be also obtained from the stoichiometric reaction of complex $\operatorname{Ru}(\mathrm{TPP}) \mathrm{CO}$ (15) with 3,5-bis(trifluoromethyl)phenyl azide. 


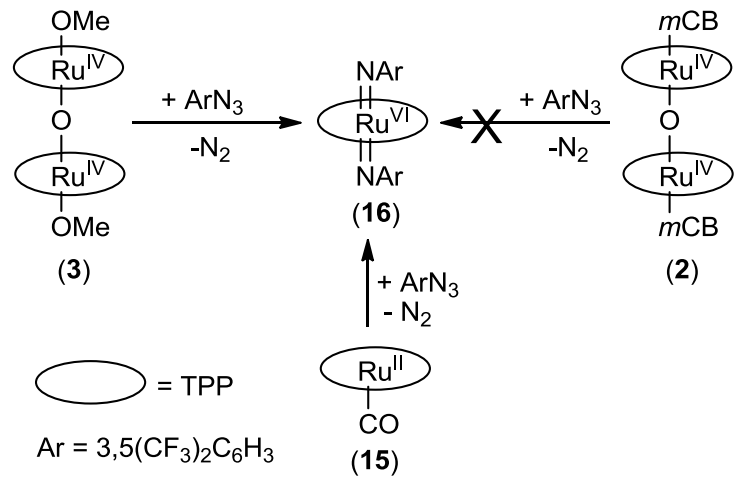

Scheme 2. Stoichiometric reaction of complexes $\mathbf{2}$ and $\mathbf{3}$ with 3,5-bis(trifluoromethyl)phenyl azide.

These results suggested that the formation of bis-imido ruthenium(VI) active species was independent from the oxidation state of the starting ruthenium complex which can be considered a pre-catalyst of the amination reaction. Achieved data also explain the catalytic inactivity shown by complex $\mathbf{2}$ in the amination of cumene, it did not react with the involved azide and consequently it was not converted into the catalytically active ruthenium(VI) intermediate.

Given the reactivity of complex 3 towards azides, it was investigated for the synthesis of bis-imido complexes which cannot be obtained by directly reacting ruthenium(II) porphyrin derivatives with aryl azides. As already reported [10, 17], this synthetic strategy was effective by using electron poor aryl azides as the starting material whereas bis-imido complexes were not obtained when electron rich aryl azides were employed. This can be due to the reaction of the initially formed mono-imido $\mathrm{Ru}^{\mathrm{IV}}$ (porphyrin)( $\left.\mathrm{ArN}\right) \mathrm{CO}$ with traces of water to yield $\mathrm{Ru}^{\mathrm{II}}$ (porphyrin) $\left(\mathrm{ArNH}_{2}\right) \mathrm{CO}$. This decomposition pathway was previously observed in the reaction between $\mathrm{Ru}^{\mathrm{II}}$ (TPP)CO and 4-tert-butylphenyl azide (4- $\left.{ }^{t} \mathrm{BuC}_{6} \mathrm{H}_{4} \mathrm{~N}_{3}\right)$ which formed $\mathrm{Ru}^{\mathrm{II}}(\mathrm{TPP})\left(4-{ }^{t} \mathrm{BuC}_{6} \mathrm{H}_{4} \mathrm{NH}_{2}\right) \mathrm{CO}(17)$ in good yields (Scheme 3) [10]. Analytical data of 17 were in accord with those of the compound synthesised by directly reacting $\mathrm{Ru}(\mathrm{TPP}) \mathrm{CO}(\mathbf{1 5})$ with $4-{ }^{t} \mathrm{BuC}_{6} \mathrm{H}_{4} \mathrm{NH}_{2}$.

The replacement of $\mathrm{Ru}^{\mathrm{II}}(\mathrm{TPP}) \mathrm{CO}(\mathbf{1 5})$ by $\left[\mathrm{Ru}^{\mathrm{IV}}(\mathrm{TPP})\left(\mathrm{OCH}_{3}\right)\right]_{2} \mathrm{O}$ (3) in the reaction with $4-{ }^{t} \mathrm{BuC}_{6} \mathrm{H}_{4} \mathrm{~N}_{3}$ afforded complex $\mathrm{Ru}^{\mathrm{VI}}(\mathrm{TPP})\left(4-{ }^{t} \mathrm{BuC}_{6} \mathrm{H}_{4} \mathrm{~N}\right)_{2}(\mathbf{1 8})$ to suggest an important effect of the metal oxidation state of the starting ruthenium complexes in the reaction with aryl azides.

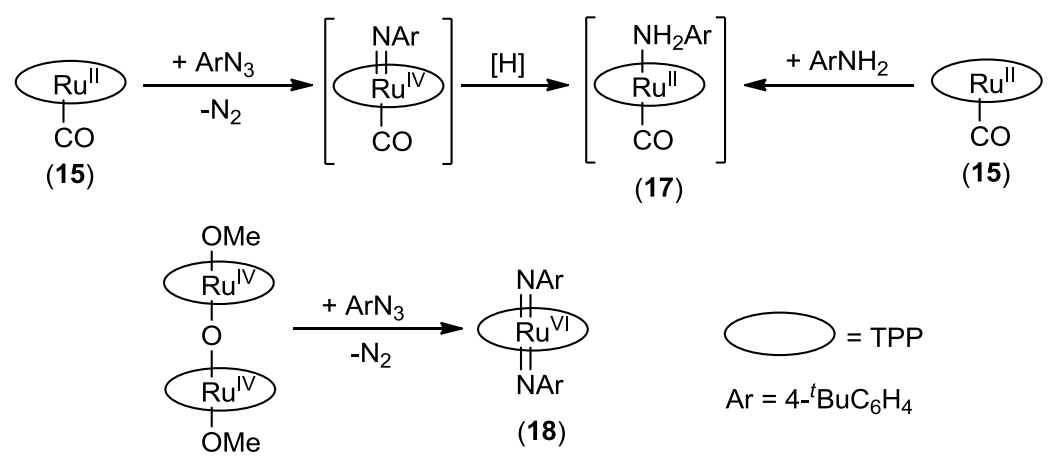

(3)

Scheme 3. Synthesis of complexes 17 and 18.

It can be suggested that the reaction between 3 and $4-{ }^{t} \mathrm{BuC}_{6} \mathrm{H}_{4} \mathrm{~N}_{3}$ followed a different pathway during which the unstable ruthenium(IV) mono-imido complex was not formed and consequently the decomposition process leading to 17 was avoided. Complex 18 was fully characterised and its reactivity was tested in both stoichiometric nitrene transfer and catalytic reactions by using cyclohexene as the substrate. In both cases complex $\mathbf{1 8}$ was completely inactive to 
indicate that the reactivity of nitrene functionalities is strongly related to the electron density on ruthenium-imido functionality which in turn depends on the electronic nature of substituents onto the 'ArN' moiety as proposed by a previous theoretical study [19].

In order to expand the reaction scope, complex $\mathbf{3}$ was reacted with a stoichiometric amount of tosyl azide, adamantyl azide and benzyl azide. In the first two cases no reaction occurred, whilst in the last case the reaction achieved unidentified products. When complex 3 was reacted with organic azides $\left(\mathrm{RN}_{3}\right)$ displaying a good $\mathrm{R}$ leaving group for electrophilic substitutions $\left(\mathrm{R}=\right.$ trityl or trimethylsilyl) a new $\mu$-oxo dimer complex $\left[\mathrm{Ru}^{\mathrm{IV}}(\mathrm{TPP})\left(\mathrm{N}_{3}\right)\right]_{2} \mathrm{O}(\mathbf{1 9})$ was obtained at room temperature (Scheme 4).

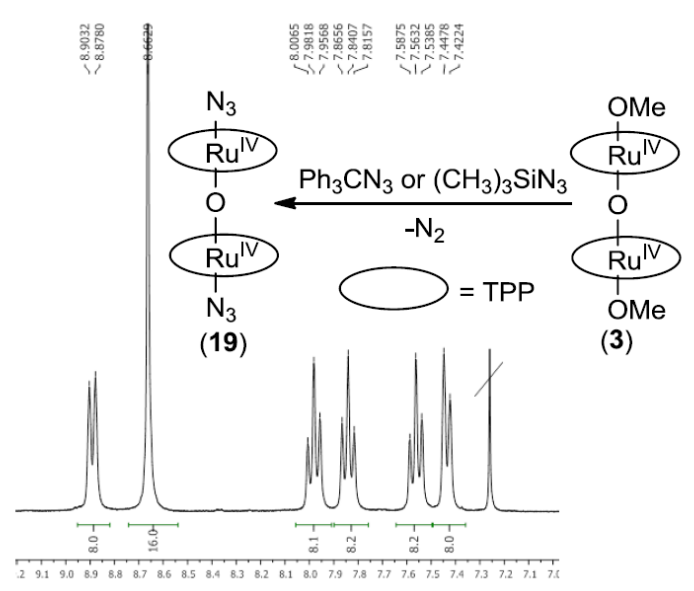

Scheme 4. Synthesis and ${ }^{1} \mathrm{H}$ NMR spectrum of complex 19.

Compound 19 was completely characterised and a slow diffusion of a $\mathrm{CHCl}_{3}$ solution of $\left[\mathrm{Ru}(\mathrm{TPP})\left(\mathrm{N}_{3}\right)\right]_{2} \mathrm{O}$ into $n$-hexane gave crystals suitable for the molecular structure determination by X-ray diffraction analysis (Figure 2, Table 2).
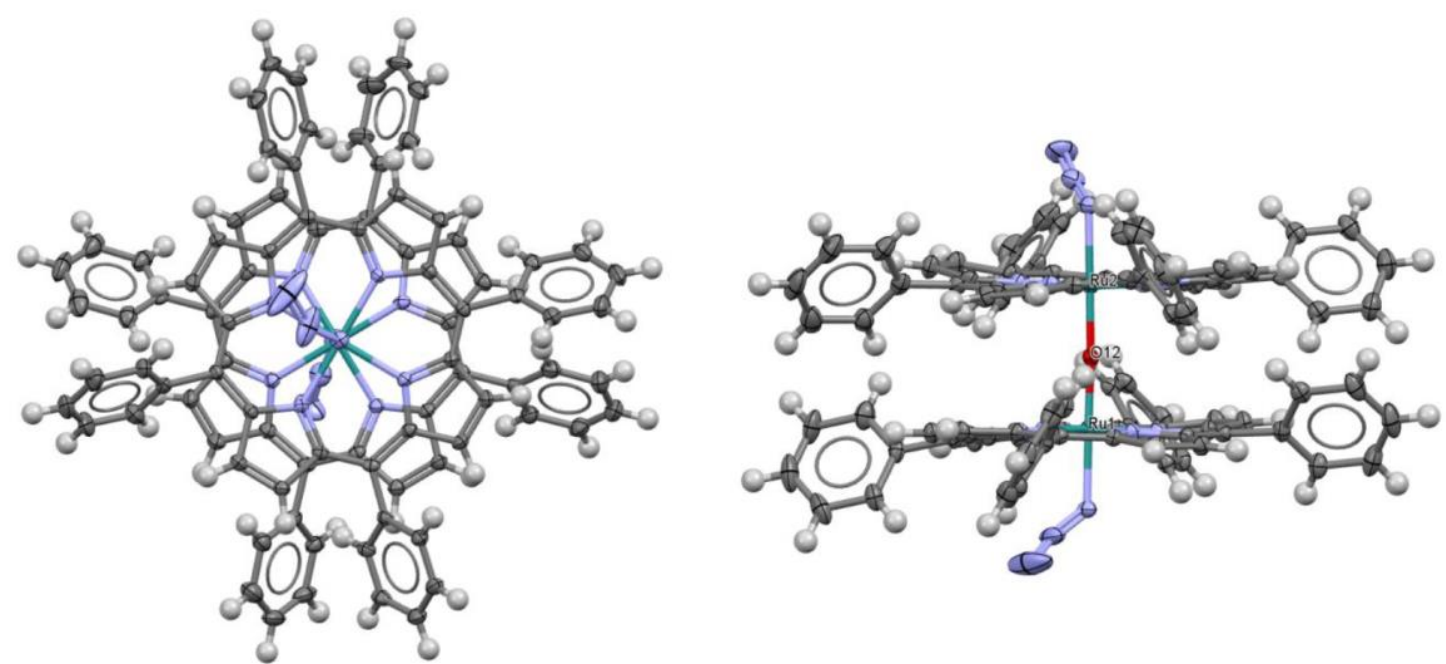

Figure 2 Top and side view of the molecular structure of 19. Atomic displacement parameters are shown as ellipsoids at $50 \%$ probability level. $\mathrm{Ru}$ atoms are in green, $\mathrm{O}$ atom is in red, $\mathrm{N}$ atoms are in blue, $\mathrm{C}$ atoms are in dark grey and $\mathrm{H}$ 
atoms in light grey. For sake of clarity, the disorder of azido group has been removed and only the dominant orientation of each group is shown.

The crystal has a monoclinic $\mathrm{P} 2{ }_{1} / \mathrm{n}$ space group, with one independent molecule in the asymmetric unit and therefore four molecules in the unit cell. At least one molecule of the crystallization solvent is localized (although refined with a disordered model). A rather large void volume (780 $\AA^{3}$ per unit cell) indicates that very likely other solvent molecules (3 per asymmetric unit) may be present, but their disorder is so strong that they cannot be easily localized even analysing the residual electron density. The molecular structure of 19 (see Figure 2) is dominated by the sandwich-like aggregation of the two porphyrins that trap the $\mathrm{O}$ atoms exactly in the middle between the two Ru atoms (1.796(3) and 1.798(3) $\AA$ for O12-Ru1 and O12-Ru2, respectively). The two average planes are almost exactly parallel to each other, although the porphyrin skeletons are not exactly flat. Moreover, the phenyl substituents clearly produce large steric hindrance and they have a conformation tilted by $50-65^{\circ}$ with respect to the porphyrin planes. Repulsions between atoms of the two porphyrin skeletons and repulsion between the phenyl rings of the two porphyrins, induce a staggeredlike conformation by making the two porphyrins rotated by ca. $28^{\circ}$ with respects to the Ru---Ru axis. This feature is rather common in M-M bonded di-porphyrin complexes with the only exception of (TPP)Mo-Re(OEP), featuring a quadruple M-M bond [28], which is perfectly eclipsed. For systems like 19, with a bridging atom making the porphyrinporphyrin distance larger, the staggered conformation is still the most common, although many eclipsed structures are also known. On each Ru atom, trans to the bridging $\mathrm{O}$, an azide group is coordinated. The potential around this ligand is rather flat, producing a large dynamic disorder that could not be eliminated even with a data collection at low temperature. Each azide has at least two orientations (only the major component is shown in Figure 2), anyway the coordination to $\mathrm{Ru}$ features the classical bent mode: $\mathrm{Ru}-\mathrm{N}-\mathrm{N}$ angles are $126.7(4)$ and $121.2(10)^{\circ}$ for the main orientations of azide at $\mathrm{Ru}(1)$ and $\mathrm{Ru}(2)$, respectively. This is in keeping with the average values known for Ru-azido complexes. The Ru-N bonds are instead somewhat shorter than the average values from the literature for $\mathrm{Ru}^{\mathrm{IV}}-\mathrm{N}_{3}$ bonds ( 2.05 vs. $2.13 \AA$ ), which could reflect the large atomic motion. The N-N distances of the azides are even more affected by the orientational disorder and the large thermal motion, therefore their accuracy is lower and does not allow precise comparisons with other structures. The bonds of the porphyrin skeleton to Ru atoms are perfectly matching the standard values $(2.05 \AA)$.

\section{EXPERIMENTAL}

\section{General}

Unless otherwise specified, all the reactions were carried out in a nitrogen atmosphere employing standard Schlenk techniques and magnetic stirring. Toluene, $n$-hexane and benzene were dried by M. Braun SPS- 800 solvent purification system. THF, $\alpha$-methylstyrene, cyclohexene, cumene and decalin over sodium and stored under nitrogen. 1,2-Dichloroethane and $\mathrm{CH}_{2} \mathrm{Cl}_{2}$ were distilled over $\mathrm{CaH}_{2}$ and immediately used. Commercial $m \mathrm{CPBA}$ (77\%) was purified using a reported procedure [29] and stored at $-20^{\circ} \mathrm{C}$. Aryl azides [27, 30], [Ru ${ }^{\mathrm{II}}(\mathrm{TPP})(\mathrm{CO})\left(\mathrm{CH} \mathrm{CH}_{3} \mathrm{OH}(\mathbf{1})[31]\right.$, $\left[\mathrm{Ru}^{\mathrm{IV}}(\mathrm{TPP})\left(\mathrm{OCH}_{3}\right)_{2}\right] \mathrm{O}(\mathbf{3})$ [21], $\mathrm{Ru}^{\mathrm{II}}(\mathrm{TPP}) \mathrm{CO}(\mathbf{1 5})$ [22] and $\mathrm{Ru}^{\mathrm{VI}}(\mathrm{TPP})\left(3,5-\left(\mathrm{CF}_{3}\right)_{2} \mathrm{C}_{6} \mathrm{H}_{3} \mathrm{~N}\right)_{2}$ (16) [17] were synthesised by methods reported in the literature or using minor modifications. The purity of hydrocarbons and aryl azides employed was checked by GC-MS or ${ }^{1} \mathrm{H}$ NMR analysis. All the other starting materials were commercial products used as received. NMR spectra were recorded at room temperature, unless otherwise specified, on a Bruker avance 300- 
DRX, operating at $300 \mathrm{MHz}$ for ${ }^{1} \mathrm{H}$, at $75 \mathrm{MHz}$ for ${ }^{13} \mathrm{C}$ and at $282 \mathrm{MHz}$ for ${ }^{19} \mathrm{~F}$. Chemical shifts (ppm) are reported relative to TMS. The ${ }^{1} \mathrm{H}$ NMR signals of the compounds described in the following have been attributed by COSY and NOESY techniques. Assignments of the resonances in ${ }^{13} \mathrm{C}$ NMR were made using the APT pulse sequence and HSQC and HMBC techniques. GC-MS analyses were performed on a Shimadzu QP5050A equipped with Supelco SLB -5 ms capillary column (L $30 \mathrm{~m} \times$ I.D. $0.25 \mathrm{~mm} \times 0.25 \mu \mathrm{m}$ film thickness). GC analyses were performed on a Shimadzu GC 2010 equipped with a Supelco SLB $-5 \mathrm{~ms}$ capillary column (L $10 \mathrm{~m} \times$ I.D. $0.1 \mathrm{~mm} \times 0.1 \mu \mathrm{m}$ film thickness). Infrared spectra were recorded on a Varian Scimitar FTS 1000 spectrophotometer. UV/Vis spectra were recorded on an Agilent $8453 \mathrm{E}$ instrument. Elemental analyses and mass spectra were recorded in the analytical laboratories of Milan University. The collected analytical data for $N$-(2-phenylpropan-2-yl)-3,5-bis(trifluoromethyl)aniline (4) [11]; $N$ phenyl-3,5-bis(trifluoromethyl)aniline (5) [11]; $N$-(1-phenylethyl)-3,5-bis(trifluoromethyl)aniline (6) [32]; $N$-(2-methyl1-phenylpropyl)-3,5-bis(trifluoromethyl)aniline (7) [17]; $N$-(3,5-bis(trifluoromethyl)phenyl)-2,3-dihydro-1 $H$-inden-1amine (8) [11]; methyl 2-((3,5-bis(trifluoromethyl)phenyl)amino)-2-phenylacetate (9) [33]; methyl 3-((3,5bis(trifluoromethyl)phenyl)amino)-3-phenylpropanoate

[33];

$N$-(cyclohex-2-en-1-yl)-3,5bis(trifluoromethyl)aniline (11) [10]; 4-(tert-butyl)- $N$-(cyclohex-2-en-1-yl)aniline (12) [10]; $N$-(cyclohex-2-en-1-yl)-4methoxyaniline (13) [10]; 2-methyl-1-(4-nitrophenyl)-2-phenylaziridine (14) [34] were in agreement with those reported in literature.

\section{Synthesis of $\left[\mathrm{Ru}^{\mathrm{IV}}(\mathrm{TPP})(m \mathrm{CB})\right]_{2} \mathrm{O}(2)$}

Complex $1\left(102 \mathrm{mg}, 1.32 \times 10^{-4} \mathrm{~mol}\right)$ was suspended in $\mathrm{CH}_{2} \mathrm{Cl}_{2}(20 \mathrm{~mL})$ and a solution of $m \mathrm{CPBA}\left(123 \mathrm{mg}, 7.13 \times 10^{-4}\right.$ mol) in $\mathrm{CH}_{2} \mathrm{Cl}_{2}(25 \mathrm{~mL})$ was added dropwise in 30 minutes and in air. The initial red suspension turned into a dark red solution. The reaction was stirred for 1.5 hours and the TLC analysis $\left(\mathrm{Al}_{2} \mathrm{O}_{3}, \mathrm{CH}_{2} \mathrm{Cl}_{2}\right)$ revealed the presence of unreacted complex 1. An additional amount of $m \mathrm{CPBA}\left(52 \mathrm{mg}, 3.0 \times 10^{-4} \mathrm{~mol}\right)$ was added and the solution was stirred for 3 hours. TLC and IR analyses (nujol, $v C=O$ of 1 at $1939 \mathrm{~cm}^{-1}$ ) showed the complete consumption of starting $\mathbf{1}$. The solution was concentrated to about $20 \mathrm{~mL}$ and filtered through a short $(5 \mathrm{~cm})$ alumina column. The product fraction was evaporated to dryness and the resulting dark solid was dried in vacuo (47 mg, 39\%).

${ }^{1} \mathrm{H}$ NMR (300 MHz, CDCl $)$ ): $\delta 8.96\left(8 \mathrm{H}, \mathrm{d}, J=7.6 \mathrm{~Hz}, \mathrm{H}_{\mathrm{o}}\right), 8.67\left(16 \mathrm{H}, \mathrm{s}, \mathrm{H}_{\beta}\right), 7.98\left(8 \mathrm{H}, \mathrm{t}, J=7.2 \mathrm{~Hz}, \mathrm{H}_{\mathrm{m}}\right), 7.82(8 \mathrm{H}$, $\left.\mathrm{t}, J=7.5 \mathrm{~Hz}, \mathrm{H}_{\mathrm{p}}\right), 7.50\left(8 \mathrm{H}, \mathrm{t}, J=7.6 \mathrm{~Hz} . \mathrm{H}_{\mathrm{m}^{\prime}}\right), 7.25\left(8 \mathrm{H}\right.$, overlaps with chloroform signal, $\left.\mathrm{H}_{\mathrm{o}^{\prime}}\right), 6.14(2 \mathrm{H}, \mathrm{d}, J=7.9 \mathrm{~Hz}$, $\left.\mathrm{H}_{3}\right), 5.66\left(2 \mathrm{H}, \mathrm{t}, J=7.8 \mathrm{~Hz}, \mathrm{H}_{2}\right), 3.54\left(2 \mathrm{H}, \mathrm{d}, J=7.8 \mathrm{~Hz}, \mathrm{H}_{1}\right), 2.74\left(2 \mathrm{H}, \mathrm{s}, \mathrm{H}_{4}\right) .{ }^{13} \mathrm{C}$ NMR $\left(75 \mathrm{MHz}, \mathrm{CDCl}_{3}\right): \delta 142.1$ $\left(\mathrm{C}_{\alpha}\right), 141.3\left(\mathrm{C}-\mathrm{C}_{\text {meso }}\right), 136.2\left(\mathrm{CH}_{\mathrm{o}^{\prime}}\right), 135.0\left(\mathrm{CH}_{\mathrm{o}}\right), 131.6\left(\mathrm{CH}_{\beta}\right), 128.9\left(\mathrm{C}-\mathrm{H}_{3}\right), 127.9\left(\mathrm{CH}_{\mathrm{p}}\right), 126.9\left(\mathrm{CH}_{\mathrm{m}}\right), 126.8\left(\mathrm{C}-\mathrm{H}_{2}\right)$, 126.6 $\left(\mathrm{CH}_{\mathrm{m}}\right), 126.1\left(\mathrm{C}-\mathrm{H}_{4}\right), 124.2\left(\mathrm{C}-\mathrm{H}_{1}\right), 121.1$ The $\mathrm{C}_{\text {meso }}, \mathrm{C}-\mathrm{Cl}$, carbonyl and C-COO-Ru signals were not detected. UV-Vis $\left(\mathrm{CH}_{2} \mathrm{Cl}_{2}\right): \lambda_{\max }(\log \varepsilon) 392 \mathrm{~nm}$ (5.42), $522 \mathrm{~nm}$ (4.24), 591 (4.25), 527 (sh). IR (ATR): $1735 \mathrm{~cm}^{-1}\left(v_{\mathrm{C}=0}\right), 1014$ $\mathrm{cm}^{-1}$ (oxidation marker band). Elemental Analysis calc. for $\mathrm{C}_{102} \mathrm{H}_{64} \mathrm{Cl}_{2} \mathrm{~N}_{8} \mathrm{O}_{5} \mathrm{Ru}_{2}: \mathrm{C}, 69.82 ; \mathrm{H}, 3.68 ; \mathrm{N}, 6.39$. Found: $\mathrm{C}$, 69.54; H, 3.42; N, 6.05. MS (ESI+): m/z $1599[\mathrm{M}-155(m \mathrm{CB})]^{+}$.

\section{Synthesis of Ru" ${ }^{\mathrm{II}}(\mathrm{TPP})\left(4-{ }^{\mathrm{t}} \mathrm{BuC}_{6} \mathrm{H}_{4} \mathrm{NH}_{2}\right) \mathrm{CO}$ (17)}

The amine $4-{ }^{t} \mathrm{BuC}_{6} \mathrm{H}_{4} \mathrm{NH}_{2}\left(97.6 \mu \mathrm{L}, 6.13 \times 10^{-4} \mathrm{~mol}\right)$ was added to a benzene $(90 \mathrm{~mL})$ suspension of $\mathrm{Ru}(\mathrm{TPP}) \mathrm{CO}(\mathbf{1 5})$ $\left(150 \mathrm{mg}, 2.02 \times 10^{-4} \mathrm{~mol}\right)$. The resulting red solution was stirred at room temperature for $30 \mathrm{~min}$, concentrated to $2 \mathrm{~mL}$ and $n$-hexane $(20 \mathrm{~mL})$ was added. The resulting red solid was collected by filtration and dried in vacuo $(155 \mathrm{mg}, 86 \%)$.

${ }^{1} \mathrm{H}$ NMR $\left(300 \mathrm{MHz}, \mathrm{C}_{6} \mathrm{D}_{6}\right): \delta 8.83\left(8 \mathrm{H}, \mathrm{s}, \mathrm{H}_{\beta}\right), 8.23\left(4 \mathrm{H}, \mathrm{d}, J=8.0 \mathrm{~Hz}, \mathrm{H}_{\mathrm{o}}\right), 8.04\left(4 \mathrm{H}, \mathrm{d}, J=8.0 \mathrm{~Hz}, \mathrm{H}_{\mathrm{o}^{\circ}}\right), 7.52(8 \mathrm{H}$, $\left.\mathrm{H}_{\mathrm{m}+\mathrm{p}}\right), 7.40\left(4 \mathrm{H}, \mathrm{H}_{\mathrm{m}}\right), 5.29\left(2 \mathrm{H}, \mathrm{d}, J=8.7 \mathrm{~Hz}, \mathrm{H}_{\mathrm{Ar}}\right), 2.41\left(2 \mathrm{H}, \mathrm{d}, J=8.7 \mathrm{~Hz}, \mathrm{H}_{\mathrm{Ar}}\right), 0.89\left(9 \mathrm{H}, \mathrm{s}, \mathrm{H}_{\mathrm{tBu}}\right) .{ }^{13} \mathrm{C}$ NMR $(75$ 
$\left.\mathrm{MHz}, \mathrm{C}_{6} \mathrm{D}_{6}\right): \delta 144.6(\mathrm{C}), 143.0(\mathrm{C}), 135.1(\mathrm{CH}), 134.3(\mathrm{CH}), 132.5(\mathrm{CH}), 127.8(\mathrm{CH}), 126.6(\mathrm{CH}), 123.8(\mathrm{CH}) . \mathrm{UV}-$ Vis $\left(\mathrm{CH}_{2} \mathrm{Cl}_{2}\right): \lambda_{\max }(\log \varepsilon) 413 \mathrm{~nm}$ (5.32), $532 \mathrm{~nm}$ (4.18). IR (ATR): $1948 \mathrm{~cm}^{-1}\left(v_{\mathrm{C}=0}\right), 1008 \mathrm{~cm}^{-1}$ (oxidation marker band). Elemental Analysis calc. for $\mathrm{C}_{55} \mathrm{H}_{43} \mathrm{~N}_{5} \mathrm{ORu}$ : C, 74.14; H, 4.86; N, 7.86. Found: C, 74.35; H, 4.95; N, 7.60. MS (ESI+): m/z 892.6 [M+1].

\section{Synthesis of $\mathrm{Ru}^{\mathrm{VI}}(\mathrm{TPP})\left(4-{ }^{t} \mathrm{BuC}_{6} \mathrm{H}_{4} \mathrm{~N}\right)_{2}(18)$}

The azide $4-{ }^{t} \mathrm{BuC}_{6} \mathrm{H}_{4} \mathrm{~N}_{3}\left(32 \mathrm{mg}, 1.8 \times 10^{-4} \mathrm{~mol}\right)$ was added to a benzene $(35 \mathrm{~mL})$ solution of complex 3 (42.0 mg, $\left.2.8 \times 10^{-5} \mathrm{~mol}\right)$. The resulting dark mixture was refluxed for 8 hours till the complete consumption of the organic azide (IR monitoring $\left.v_{\mathrm{N}=\mathrm{N}}=2124-2092 \mathrm{~cm}^{-1}\right)$. The solution was concentrated to $5 \mathrm{~mL}$ and $n$-hexane $(15 \mathrm{~mL})$ was added. By cooling the solution in an ice bath, the formation of a violet precipitate was observed. The dark violet solid was collected by filtration and dried in vacuo. (55\% yield). ${ }^{1} \mathrm{H} \mathrm{NMR}\left(300 \mathrm{MHz}, \mathrm{C}_{6} \mathrm{D}_{6}\right): \delta 8.93\left(8 \mathrm{H}, \mathrm{s}, \mathrm{H}_{\beta}\right), 8.12\left(8 \mathrm{H}, \mathrm{m}, \mathrm{H}_{\mathrm{Ph}-}\right.$ ortho), $7.47\left(12 \mathrm{H}, \mathrm{m}, \mathrm{H}_{\mathrm{Ph} \text {-meta and -para }}\right), 5.78\left(4 \mathrm{H}, \mathrm{d}, J=8.7 \mathrm{~Hz}, \mathrm{H}_{\mathrm{Ar}-\text { meta }}\right), 2.77$ (4H, d, $\left.J=8.7 \mathrm{~Hz}, \mathrm{H}_{\mathrm{Ar}-\text { ortho }}\right), 0.64(9 \mathrm{H}, \mathrm{s}$, $\left.\mathrm{H}_{\mathrm{tBu}}\right) .{ }^{13} \mathrm{C}$ NMR $\left(100 \mathrm{MHz}, \mathrm{C}_{6} \mathrm{D}_{6}\right): \delta 143.0\left(\mathrm{C}_{\alpha}\right), 134.7\left(\mathrm{CH}_{\mathrm{Ph}-\text { ortho }}\right), 131.6\left(\mathrm{CH}_{\beta}\right), 126.7\left(\mathrm{CH}_{\mathrm{Ph} \text {-meta and -para }}\right), 123.1(\mathrm{CH} \mathrm{H} \mathrm{Ar}-$ meta), $119.1\left(\mathrm{CH}_{\mathrm{Ar}-o r t h o}\right), 30.75\left(\mathrm{CH}_{\mathrm{tBu}}\right)$. A little amount of the complex decomposed during the carbon spectrum acquisition, five quaternary carbons were not detected. UV-Vis $\left(\mathrm{CH}_{2} \mathrm{Cl}_{2}\right): \lambda_{\max }(\log \varepsilon) 39 \mathrm{~nm}(4.59), 532 \mathrm{~nm}(3.66)$. IR (ATR): $2954 \mathrm{~cm}^{-1}\left(v_{\mathrm{C}-\mathrm{H}}\right), 1012 \mathrm{~cm}^{-1}$ (oxidation marker band). Elemental Analysis calc. for $\mathrm{C}_{64} \mathrm{H}_{54} \mathrm{~N}_{6} \mathrm{Ru}: \mathrm{C}, 76.24 ; \mathrm{H}$, 5.40; N, 8.34; Found: C, 76.55; H, 5.62; N, 8.11. MS (ESI+): m/z 1009.2 [M+1].

\section{Synthesis of $\left[R u^{I V}(T P P)\left(N_{3}\right)\right]_{2} O(19)$}

Method $A$ : $\left[\mathrm{Ru}^{\mathrm{IV}}(\mathrm{TPP})(\mathrm{OMe})\right]_{2} \mathrm{O}(3)\left(102 \mathrm{mg}, 6.77 \times 10^{-5} \mathrm{~mol}\right)$ was dissolved in benzene $(20 \mathrm{~mL})$ and trimethylsilyl azide was added $\left(36 \mu 1,2.7 \times 10^{-4} \mathrm{~mol}\right)$. The solution immediately turned form dark red to dark green, the mixture was stirred for 1 hour at RT and monitored by TLC and IR analyses. The solution was evaporated to dryness and $n$-hexane $(10 \mathrm{~mL})$ was added to the residue. The resulting dark violet solid was collected by filtration and washed with $n$-hexane $(10 \mathrm{~mL})(90 \mathrm{mg}, 87 \%)$. Method B: [Ru(TPP)(OMe) $]_{2} \mathrm{O}(\mathbf{3})\left(108 \mathrm{mg}, 7.17 \times 10^{-5} \mathrm{~mol}\right)$ was dissolved in benzene $(30 \mathrm{~mL})$ and trityl azide was added $\left(217 \mathrm{mg}, 7.60 \times 10^{-4} \mathrm{~mol}\right)$. The solution was heated to reflux for $4 \mathrm{~h}$ and the reaction was monitored by TLC and IR analyses. The solution was evaporated to dryness, the crude was washed with $n$-hexane $(2 \times 30 \mathrm{~mL})$ and purified by chromatography $\left(\mathrm{Al}_{2} \mathrm{O}_{3}, n\right.$-hexane $\left./ \mathrm{CH}_{2} \mathrm{Cl}_{2}=6: 4\right)$. A dark violet solid was obtained (46 mg, $41 \%)$.

${ }^{1} \mathrm{H}$ NMR $\left(300 \mathrm{MHz}, \mathrm{CDCl}_{3}\right): \delta 8.87\left(8 \mathrm{H}, \mathrm{d}, J=7.6 \mathrm{~Hz}, \mathrm{H}_{\mathrm{o}}\right), 8.65\left(16 \mathrm{H}, \mathrm{s}, \mathrm{H}_{\beta}\right), 7.97\left(8 \mathrm{H}, \mathrm{t}, J=7.6 \mathrm{~Hz}, \mathrm{H}_{\mathrm{m}}\right), 7.84(8 \mathrm{H}$, $\left.\mathrm{t}, J=7.5 \mathrm{~Hz}, \mathrm{H}_{\mathrm{p}}\right), 7.56\left(8 \mathrm{H}, \mathrm{t}, J=7.5 \mathrm{~Hz}, \mathrm{H}_{\mathrm{m}}\right), 7.43\left(8 \mathrm{H}, \mathrm{d}, J=7.6 \mathrm{~Hz}, \mathrm{H}_{\mathrm{o}}\right) \cdot{ }^{13} \mathrm{C} \mathrm{NMR}\left(75 \mathrm{MHz}, \mathrm{CDCl}_{3}\right): \delta 141.69$ $\left(\mathrm{C}_{\alpha}\right), 141.22\left(C-\mathrm{C}_{\text {meso }}\right), 136.27\left(\mathrm{CH}_{\mathrm{o}}\right), 135.41\left(\mathrm{CH}_{\mathrm{o}}\right), 131.78\left(\mathrm{CH}_{\beta}\right), 127.97\left(\mathrm{CH}_{\mathrm{p}}\right), 127.00\left(\mathrm{CH}_{\mathrm{m}}\right), 126.62\left(\mathrm{CH}_{\mathrm{m}}\right), 120.83$ $\left(\mathrm{C}_{\text {meso }}\right)$. UV-Vis $\left(\mathrm{CH}_{2} \mathrm{Cl}_{2}\right): \lambda_{\max }(\log \varepsilon) 280 \mathrm{~nm}$ (4.43), $393 \mathrm{~nm}$ (5.46), $554 \mathrm{~nm}$ (4.18), $592 \mathrm{~nm}$ (4.21). IR (ATR): 2023 $\mathrm{cm}^{-1}\left(v_{\mathrm{N}=\mathrm{N}}\right), 1012 \mathrm{~cm}^{-1}$ (oxidation marker band). Elemental Analysis calc. for $\mathrm{C}_{88} \mathrm{H}_{56} \mathrm{~N}_{14} \mathrm{ORu}_{2}: \mathrm{C}, 69.19 ; \mathrm{H}, 3.69 ; \mathrm{N}$, 12.84; O, 1.05; Ru, 13.23. Found: C, 69.31; H, 3.55; N, 12.47. MS (ESI-): m/z 1529.0 [M+1]. X-ray quality crystals were obtained by slow diffusion of a $\mathrm{CHCl}_{3}$ solution of $\left[\mathrm{Ru}(\mathrm{TPP})\left(\mathrm{N}_{3}\right)\right]_{2} \mathrm{O}$ into $n$-hexane (see Table 2 and SI).

\section{General procedure for catalytic reactions}

Method A: In a typical run, complex $3\left(39.0 \mathrm{mg}, 2.60 \times 10^{-5} \mathrm{~mol}\right)$ and the opportune amount of azide were dissolved into the desired hydrocarbon substrate $(25 \mathrm{~mL})$. The reaction solution was then heated to reflux by using a preheated oil 
bath. The consumption of the azide was monitored by TLC up to the point that its spot was no longer observable, and then by IR spectroscopy measuring the characteristic azide absorbance in the region $2095-2130 \mathrm{~cm}^{-1}$. The reaction was considered to be finished when the absorbance of the latter peak was below 0.03 (using a $0.5 \mathrm{~mm}$ thick cell). The solution was then concentrated to dryness and the residue was purified by flash chromatography using $n$-hexane/ethyl acetate $=9: 1$ as the eluent mixture or analysed by ${ }^{1} \mathrm{H}$ NMR with 2,4-dinitrotoluene as the internal standard. All reaction

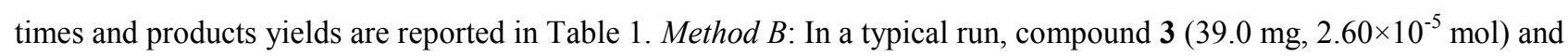
the opportune amount of azide and hydrocarbon were dissolved in benzene $(25 \mathrm{~mL})$. The solution was then heated to reflux by using a preheated oil bath. The consumption of the azide was monitored by TLC until its spot was no longer observable, and then by IR spectroscopy measuring the characteristic azide absorbance in the region $2095-2130 \mathrm{~cm}^{-1}$. The reaction was considered to be finished when the absorbance of the latter peak was below 0.03 (using a $0.5 \mathrm{~mm}$ thick cell). The solution was then concentrated to dryness and the residue was purified by flash chromatography using $n$-hexane/ethyl acetate $=9: 1$ as the eluent mixture or analysed by ${ }^{1} \mathrm{H}$ NMR with 2,4-dinitrotoluene as the internal standard. All reaction times and products yields are reported in Table 1.

\section{Single crystal X-ray diffraction of $\left[\mathrm{Ru}^{\mathrm{IV}}(\mathrm{TPP})\left(\mathrm{N}_{3}\right)\right]_{2} \mathrm{O}(19)$}

A crystal of species 19, was mounted in air and used for X-ray structure determination. All measurements were made on a Rigaku Oxford Diffraction SuperNova area-detector diffractometer using mirror optics monochromated Mo K $\alpha$ radiation $(\lambda=0.71073 \AA)$ and $\mathrm{Al}$ filtered [35]. The unit cell constants and an orientation matrix for data collection were obtained from a least-squares refinement of the setting angles of reflections in the range $1.6^{\circ}<\theta<25.2^{\circ}$. A total of 554 frames were collected using $\omega$ scans, with $15+15$ seconds exposure time, a rotation angle of $1.0^{\circ}$ per frame, a crystaldetector distance of $65.1 \mathrm{~mm}$, at $\mathrm{T}=173$ (2) K. Data reduction was performed using the CrysAlisPro program [36]. The intensities were corrected for Lorentz and polarization effects, and an absorption correction based on the multi-scan method using SCALE3 ABSPACK in CrysAlisPro was applied. Data collection and refinement parameters are given in Table 2.

The structure was solved by direct methods using SHELXS-97 [37], which revealed the positions of all nonhydrogen atoms of the title compound. The non-hydrogen atoms were refined anisotropically. All H-atoms were placed in geometrically calculated positions and refined using a riding model where each $\mathrm{H}$-atom was assigned a fixed isotropic displacement parameter with a value equal to $1.2 \mathrm{Ueq}$ of its parent atom.

Refinement of the structure was carried out on $\mathrm{F}^{2}$ using full-matrix least-squares procedures, which minimized the function $\Sigma \mathrm{w}\left(\mathrm{F}_{\mathrm{o}}^{2}-\mathrm{F}_{\mathrm{c}} 2\right)^{2}$. The weighting scheme was based on counting statistics and included a factor to downweight the intense reflections. All calculations were performed using the SHELXL-972 program.

\section{Insert Table 2}

\section{CONCLUSIONS}

This work deals with the synthesis of $\mu$-oxo dimeric ruthenium(IV) porphyrin species to investigate their catalytic efficiency in amination reactions by using aryl azides as nitrogen sources. Recorded data were compared to those achieved by using ruthenium(II) porphyrins in order to study the effect of the metal oxidation state on the catalytic 
performance of ruthenium porphyrin species. Similar catalytic results were achieved to indicate the probable formation of same active intermediates during the amination and in fact, the study of the reactivity of ruthenium(IV) species towards aryl azides disclosed the formation in both cases of a bis-imido ruthenium(VI) intermediate which is responsible for the nitrene transfer reaction. The stoichiometric reaction between $\left[\mathrm{Ru}^{\mathrm{IV}}(\mathrm{TPP})\left(\mathrm{OCH}_{3}\right)\right]_{2} \mathrm{O}(\mathbf{3})$ and 4- ${ }^{t} \mathrm{BuC}_{6} \mathrm{H}_{4} \mathrm{~N}_{3}$ or $\mathrm{RN}_{3}\left(\mathrm{R}=\mathrm{Ph}_{3} \mathrm{C}\right.$ or $\left.\left(\mathrm{CH}_{3}\right)_{3} \mathrm{Si}\right)$ afforded $\mathrm{Ru}^{\mathrm{VI}}(\mathrm{TPP})\left(4{ }^{t} \mathrm{BuC}_{6} \mathrm{H}_{4} \mathrm{~N}\right)_{2}(\mathbf{1 8})$ and $\left[\mathrm{Ru}^{\mathrm{IV}}(\mathrm{TPP})\left(\mathrm{N}_{3}\right)\right]_{2} \mathrm{O}(\mathbf{1 9})$ respectively. Both complexes were fully characterised and the molecular structure of complex 19 was determinated by X-ray single crystal diffraction.

\section{Supporting Information}

Crystallographic data have been deposited at the Cambridge Crystallographic Data Center (CCDC) under deposition numbers CCDC 1450326. Copies can be obtained on request, free-of-charge, via www.ccdc.cam.ac.uk/conts/retrieving.html or from the Cambridge. Crystallographic Data Center, 12 Union Road, Cambridge CB2 1EZ, UK (fax: +44 1223-336-033 or email: deposit@ccdc.cam.ac.uk).

\section{REFERENCES}

1. Yamaguchi J, Yamaguchi AD and Itami K. Angew Chem Int Ed 2012; 51: 8960-9009.

2. Uchida T and Katsuki T. Chem. Rec. 2014; 14: 117-129.

3. Fantauzzi S, Caselli A and Gallo E. Dalton Trans 2009; 5434-5443.

4. Collet F, Lescot C and Dauban P. Chem. Soc. Rev. 2011; 40: 1926-1936.

5. Chang JWW, Ton TMU and Chan PWH. Chem. Rec. 2011; 11: 331-357.

6. Liu Y, Chen G-Q, Tse C-W, Guan X, Xu Z-J, Huang J-S and Che C-M. Chem. Asian J. 2015; 10: 100-105.

7. Intrieri D, Zardi P, Caselli A and Gallo E. Chem. Commun. 2014; 50: 11440-11453.

8. Tseberlidis G, Zardi P, Caselli A, Cancogni D, Fusari M, Lay L and Gallo E. Organometallics 2015; 34: 3774-3781.

9. Intrieri D, Mariani M, Caselli A, Ragaini F and Gallo E. Chem. Eur. J. 2012; 18: 10487-10490.

10. Intrieri D, Caselli A, Ragaini F, Macchi P, Casati N and Gallo E. Eur. J. Inorg. Chem. 2012; 569-580.

11. Intrieri D, Caselli A, Ragaini F, Cenini S and Gallo E. J. Porphyrins Phthalocyanines 2010; 14: $732-740$.

12. Manca G, Mealli C, Carminati DM, Intrieri D and Gallo E. Eur. J. Inorg. Chem. 2015; 4885-4893.

13. Chan K-H, Guan X, Lo VK-Y and Che C-M. Angew. Chem. Int. Ed. 2014; 53: 2982-2987.

14. Xiao W, Wei J, Zhou C-Y and Che C-M. Chem. Commun. 2013; 49: 4619-4621.

15. Xiao W, Zhou C-Y and Che C-M. Chem. Commun. 2012; 48: 5871-5873.

16. Guo Z, Guan X, Huang J-S, Tsui W-M, Lin Z and Che C-M. Chem. Eur. J. 2013; 19: 11320-11331.

17. Fantauzzi S, Gallo E, Caselli A, Ragaini F, Casati N, Macchi P and Cenini S. Chem. Commun. 2009; 3952-3954.

18. Zardi P, Pozzoli A,Ferretti F, Manca G, Mealli C and Gallo E Dalton Trans. 2015; 44: 10479-10489.

19. Manca G, Gallo E, Intrieri D and Mealli C. ACS Catal. 2014; 823-832.

20. Au S-M, Huang J-S, Yu W-Y, Fung W-H and Che C-M. J. Am. Chem. Soc. 1999; 121: 9120-9132.

21. Collman JP, Barnes CE, Brothers PJ, Collins TJ, Ozawa T, Gallucci JC and Ibers JA J. Am. Chem. Soc. 1984; 106: 5151-5163.

22. Gallo E, Caselli A, Ragaini F, Fantauzzi S, Masciocchi N, Sironi A and Cenini S. Inorg. Chem. 2005; 44: 20392049 
23. Groves JT and Quinn R. Inorg. Chem. 1984; 23: 3844-3846.

24. Masuda H, Taga T, Osaki K, Sugimoto H, Mori M and Ogoshi H. J. Am. Chem. Soc. 1981; 103: 2199-2203.

25. Vanover E, Huang Y, Xu L, Newcomb M and Zhang R. Org. Lett. 2010; 12: 2246-2249.

26. Zhang R, Vanover E, Luo W and Newcomb M. Dalton Trans. 2014; 43: 8749-8756.

27. Fantauzzi S, Gallo E, Caselli A, Piangiolino C, Ragaini F and Cenini S. Eur. J. Org. Chem. 2007; 6053-6059.

28. Collman JP, Boulatov R and Jameson GB. Angew. Chem. Int. Ed. 2001; 40: 1271-1274.

29. Bortolini O, Campestrini S, Di Furia F, Modena G, J. Org. Chem. 1987; 52: 5093-5095.

30. Tanno M, Sueyoshi S and Kamiya S. Chem. Pharm. Bull. 1982; 30: 3125-3132.

31. Rillema DP, Nagle JK, Barringer LF, Jr. and Meyer TJ. J. Am. Chem. Soc. 1981; 103: 56-62.

32. Ragaini F, Penoni A, Gallo E, Tollari S, Li Gotti C, Lapadula M, Mangioni E and Cenini S. Chem. Eur. J. 2003; 9: 249-259.

33. Zardi P, Caselli A, Macchi P, Ferretti F and Gallo E. Organometallics 2014; 33: 2210-2218.

34. Caselli A, Gallo E, Fantauzzi S, Morlacchi S, Ragaini F and Cenini S. Eur. J. Inorg. Chem. 2008; $3009-3019$.

35. Macchi P, Burgi H-B, Chimpri AS, Hauser J and Gal Z. J Appl. Crystallogr. 2011; 44: 763-771.

36. Rigaku-Oxford Diffraction. 2015 CrysAlisPro Version 171.37.33

37. Sheldrick G. Acta Cryst. A 2008; 64: 112-122. 


\section{GRAPICAL ABSTRACT}

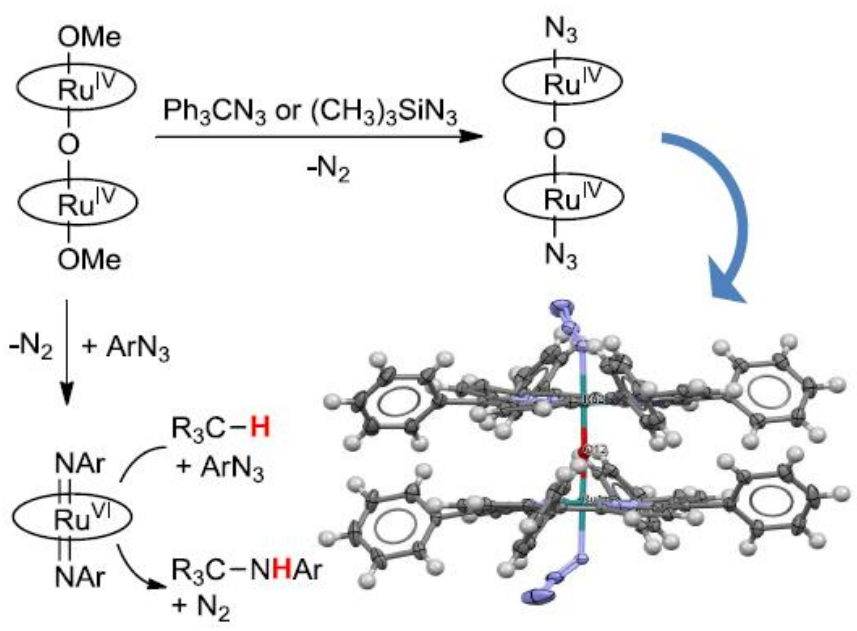

This work describes the synthesis of new ruthenium(IV) $\mu$-oxo porphyrin complexes of general formula $\left[\mathrm{Ru}^{\mathrm{IV}}(\mathrm{TPP})(\mathrm{X})\right]_{2} \mathrm{O}$ which reacted with organic azides in both stoichiometric and catalytic amination reactions. The reaction of $\left[\mathrm{Ru}^{\mathrm{IV}}(\mathrm{TPP})\left(\mathrm{OCH}_{3}\right)\right]_{2} \mathrm{O}$ with $\mathrm{Ph}_{3} \mathrm{CN}_{3}$ or $\left(\mathrm{CH}_{3}\right)_{3} \mathrm{SiN}_{3}$ yielded the new compound $\left[\mathrm{Ru}^{\mathrm{IV}}(\mathrm{TPP})\left(\mathrm{N}_{3}\right)\right]_{2} \mathrm{O}$ which was fully characterised. 


\section{Tables}

Table 1. Synthesis of aza-derivatives 4-14 catalysed by $\left[\mathrm{Ru}^{\mathrm{IV}}(\mathrm{TPP})\left(\mathrm{OCH}_{3}\right)\right]_{2} \mathrm{O}(3)^{a}$

\begin{tabular}{|c|c|c|c|c|c|}
\hline entry & reagent & product & $\mathrm{Ar}$ & $\mathrm{t}(\mathrm{h})^{b}$ & yield $(\%)^{c}$ \\
\hline 1 & & & $3,5\left(\mathrm{CF}_{3}\right)_{2} \mathrm{C}_{6} \mathrm{H}_{4}, 4$ & 0.5 & 65 \\
\hline 2 & & & $3,5\left(\mathrm{CF}_{3}\right)_{2} \mathrm{C}_{6} \mathrm{H}_{4}, \mathbf{5}$ & 1.5 & 55 \\
\hline 3 & & & $3,5\left(\mathrm{CF}_{3}\right)_{2} \mathrm{C}_{6} \mathrm{H}_{4}, 6$ & 5.5 & 80 \\
\hline 4 & & & $3,5\left(\mathrm{CF}_{3}\right)_{2} \mathrm{C}_{6} \mathrm{H}_{4}, 7$ & 2 & 65 \\
\hline 5 & & & $3,5\left(\mathrm{CF}_{3}\right)_{2} \mathrm{C}_{6} \mathrm{H}_{4}, \mathbf{8}$ & 1.5 & 90 \\
\hline $6^{d}$ & & & $3,5\left(\mathrm{CF}_{3}\right)_{2} \mathrm{C}_{6} \mathrm{H}_{4}, 9$ & 6 & 44 \\
\hline $7^{d}$ & & & $3,5\left(\mathrm{CF}_{3}\right)_{2} \mathrm{C}_{6} \mathrm{H}_{4}, \mathbf{1 0}$ & 5 & 70 \\
\hline $8^{e}$ & & & $\begin{array}{l}3,5\left(\mathrm{CF}_{3}\right)_{2} \mathrm{C}_{6} \mathrm{H}_{4}, 11 \\
4\left({ }^{t} \mathrm{Bu}\right) \mathrm{C}_{6} \mathrm{H}_{5}, 12 \\
4\left(\mathrm{OCH}_{3}\right) \mathrm{C}_{6} \mathrm{H}_{5}, 13\end{array}$ & $\begin{array}{l}0.75 \\
3 \\
1.5\end{array}$ & $\begin{array}{l}65 \\
60 \\
20\end{array}$ \\
\hline $9^{f}$ & & & $3,5\left(\mathrm{CF}_{3}\right)_{2} \mathrm{C}_{6} \mathrm{H}_{4}, 14$ & 0.1 & 99 \\
\hline
\end{tabular}

${ }^{a}$ Catalyst $3\left(2.6 \times 10^{-5} \mathrm{~mol}, 1.0 \%\right.$ with respect to $\left.\mathrm{ArN}_{3}\right)$ in $25.0 \mathrm{~mL}$ of refluxing substrate. ${ }^{b}$ Time required for the complete azide conversion monitored by IR spectroscopy. ${ }^{c}$ Determined by ${ }^{1} \mathrm{H}$ NMR spectroscopy $\left(2,4\right.$-dinitrotoluene as the internal standard) ${ }^{d}$ Catalytic ratio 3 (2.6 $\times 10^{-4}$ mol $) /$ azide/substrate $=1: 10: 250$ in $25.0 \mathrm{~mL}$ of refluxing benzene. ${ }^{e}$ Catalytic ratio $3\left(5.2 \times 10^{-5}\right.$ mol $) /$ azide/substrate $=1: 50: 250$ in $25.0 \mathrm{~mL}$ of refluxing benzene. ${ }^{f}$ Catalytic ratio $3\left(2.6 \times 10^{-5} \mathrm{~mol}\right) /$ azide/substrate $=1: 100: 250$ in $25.0 \mathrm{~mL}$ of refluxing benzene. 
Table 2. Crystal data and structure refinement for 19.

Empirical formula

Formula weight

Temperature

Wavelength

Crystal system

Space group

Unit cell dimensions

Volume

Z

Density (calculated)

Absorption coefficient

$\mathrm{F}(000)$

Crystal size

Theta range for data collection

Index ranges

Reflections collected

Independent reflections

Completeness to theta $=25.000^{\circ}$

Refinement method

Data / restraints / parameters

Goodness-of-fit on $\mathrm{F}^{2}$

Final $\mathrm{R}$ indices [I>2sigma(I)]

$\mathrm{R}$ indices (all data)

Largest diff. peak and hole
$\mathrm{C}_{88} \mathrm{H}_{56} \mathrm{~N}_{14} \mathrm{ORu}_{2} . \mathrm{CHCl}_{3}$

1646.96

173(2) K

$0.71069 \AA$

Monoclinic

P $2{ }_{1} / \mathrm{n}$

$\begin{array}{ll}\mathrm{a}=13.89880(10) \AA & \alpha=90^{\circ} . \\ \mathrm{b}=31.9489(3) \AA & \beta=107.5230(10)^{\circ} . \\ \mathrm{c}=18.4576(2) \AA & \gamma=90^{\circ} .\end{array}$

7815.79(13) $\AA^{3}$

4

$1.399 \mathrm{Mg} / \mathrm{m}^{3}$

$0.547 \mathrm{~mm}^{-1}$

3340

$0.3 \times 0.2 \times 0.1 \mathrm{~mm}^{3}$

1.621 to $25.347^{\circ}$.

$-16<=\mathrm{h}<=16,-38<=\mathrm{k}<=38,-22<=\mathrm{l}<=22$

58274

$14312[\mathrm{R}(\mathrm{int})=0.0336]$

$100.0 \%$

Full-matrix least-squares on $\mathrm{F}^{2}$

14312 / 72 / 1031

1.041

$\mathrm{R}_{1}=0.0663, \mathrm{wR}_{2}=0.1932$

$\mathrm{R}_{1}=0.0754, \mathrm{wR}_{2}=0.2030$

5.011 and -1.593 e. $\AA^{-3}$ 
Figures

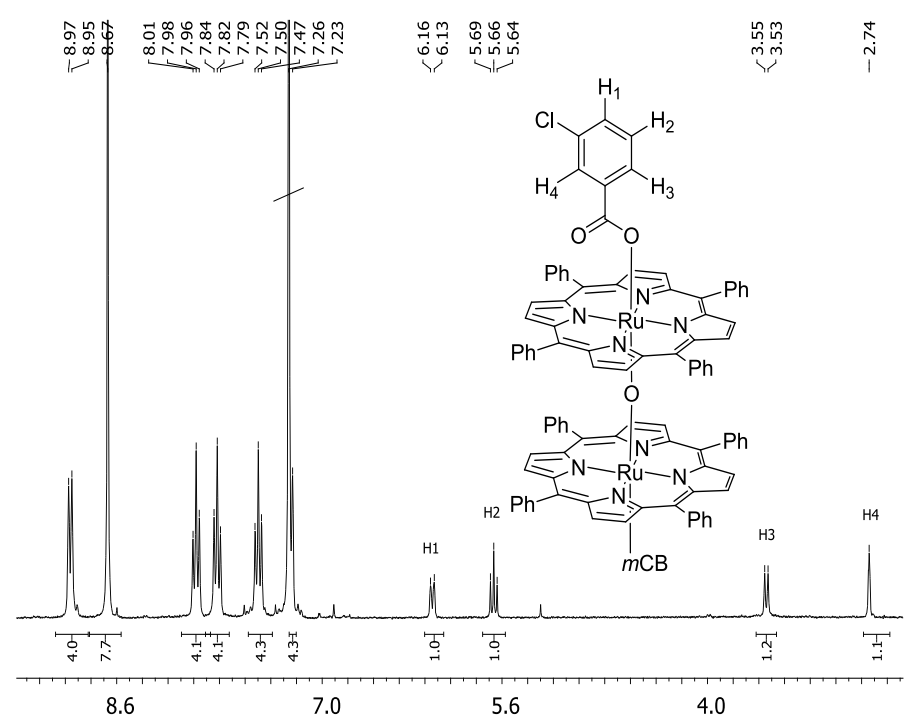

Figure 1. Structure and ${ }^{1} \mathrm{H}$ NMR spectrum of $\left[\mathrm{Ru}^{\mathrm{IV}}(\mathrm{TPP})(m \mathrm{CB})\right]_{2} \mathrm{O}$ complex (2). 

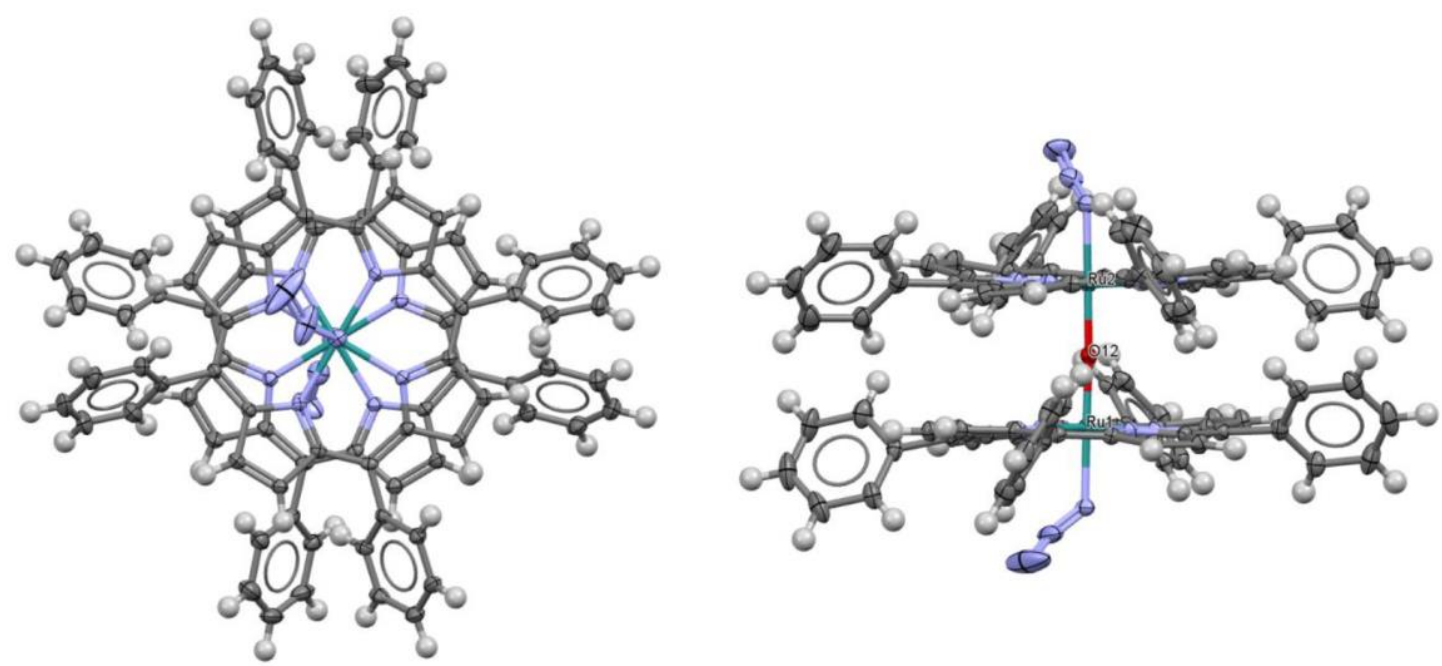

Figure 2 Top and side view of the molecular structure of 19. Atomic displacement parameters are shown as ellipsoids at $50 \%$ probability level. Ru atoms are in green, $\mathrm{O}$ atom is in red, $\mathrm{N}$ atoms are in blue, $\mathrm{C}$ atoms are in dark grey and $\mathrm{H}$ atoms in light grey. For sake of clarity, the disorder of azido group has been removed and only the dominant orientation of each group is shown. 


\section{Schemes}

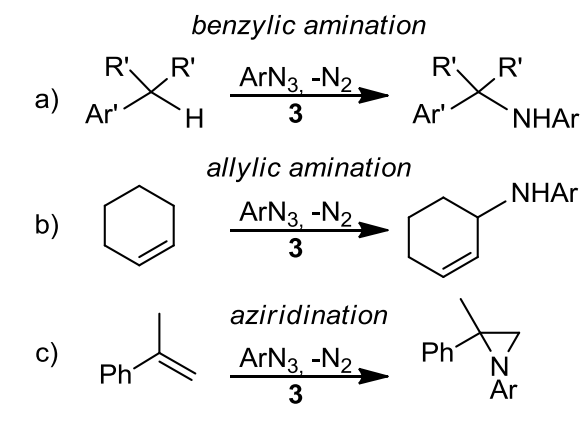

Scheme 1. Nitrene transfer reactions catalysed by complex 3 . 


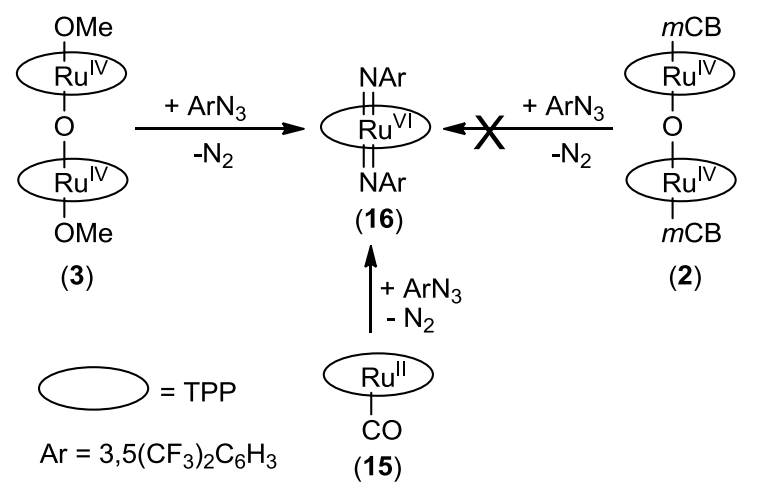

Scheme 2. Stoichiometric reaction of complexes 2 and 3 with 3,5-bis(trifluoromethyl)phenyl azide. 


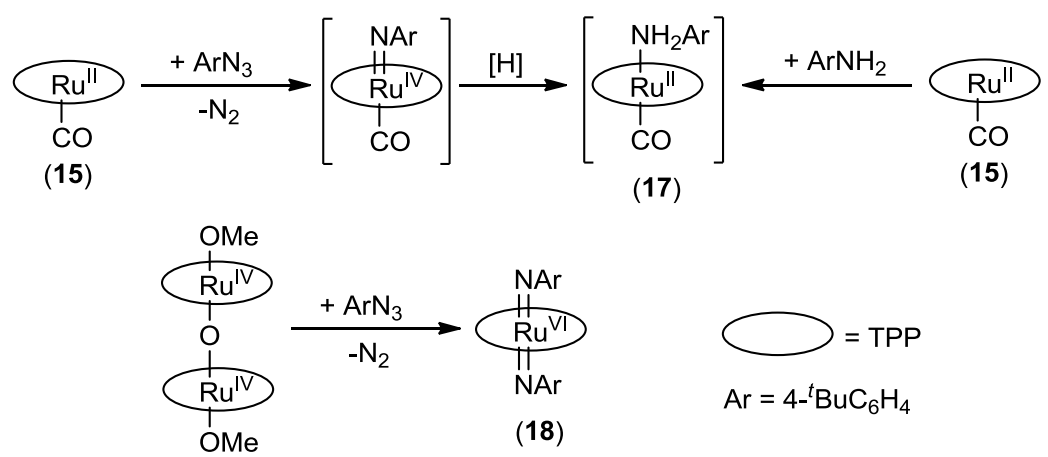

(3)

Scheme 3. Synthesis of complexes $\mathbf{1 7}$ and $\mathbf{1 8}$. 


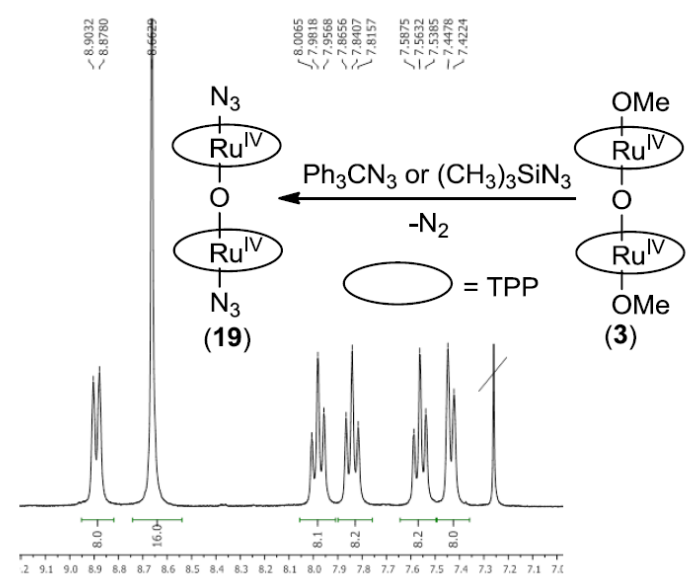

Scheme 4. Synthesis and ${ }^{1} \mathrm{H}$ NMR sp 